\title{
Gamma-Aminobutyric Acid Type B Receptor Subunit 2
}

National Cancer Institute

\section{Source}

National Cancer Institute. Gamma-Aminobutyric Acid Type B Receptor Subunit 2. NCI

Thesaurus. Code C101483.

Gamma-aminobutyric acid type B receptor subunit 2 (941 aa, $106 \mathrm{kDa}$ ) is encoded by the human GABBR2 gene. This protein plays a role in the mediation of GABA-dependent signaling. 